\title{
Diagnostic mistake and wrong treatment of cutaneous myiasis by Cochliomyia hominivorax (Coquerel) (Diptera: Calliphoridae)
}

\section{José Henry Osorio}

Proffesor. Departamento de Ciencias Básicas de la Salud. Universidad de Caldas. Manizales, Colombia. PhD, Laboratorio de Investigación en Metabolismo. Universidad de Manizales. Manizales, Colombia. Email: jose.osorio_o@ucaldas.edu.co.

\begin{abstract}
There are many reports of myiasis in humans. However for some clinicians still remain some questions about the convenience of early treatment when facing this kind of problems. The present study shows how doctors have to be clear to treat myiasis, based on a diagnostic mistake and wrong treatment of a 67 year-old woman who resided in an urban area of Chinchiná, a municipality located in the department of Caldas in Colombia, who was parasitized by larvae of the screwworm, Cochliomyia hominivorax (Coquerel) (Diptera: Calliphoridae). The objective of the present work is to analyze a real clinical situation, trying to clarify the difference between natural infestations vs therapeutic treatment using maggots, and how treatment has to be perform as prompt as possible for natural infestations, in order to avoid undesirable consequences for patients suffering myiasis. It can be concluded that occurrences of traumatic myiasis in humans represent serious public health concerns, then health personnel dealing with patients presenting myiasis, have to initiate immediate treatment to eliminate the larvae using the available methods in order to guard the patient's security.
\end{abstract}

Keywords: Calliphoridae; Cochliomyia hominivorax; Ectoparasites; Public health entomology.

\section{Introduction}

The infestation by maggots of live animals and humans is called "myiasis" (Aggarwal et al., 2014). The concept is derived from the Greek word, myia, which means fly. Hope introduced in 1840 the term referring to the infestation tissues of live human and vertebrate animals with dipterous (two-winged) larvae (maggots) (Robbins, 2010). For health care professionals as well as for patients, myiasis is considered, in general terms, an embarrassing and repugnant disease
Received

June 10, 2016

Accepted

June 24, 2016

Released June 30, 2016

Open Acess Full Text Article

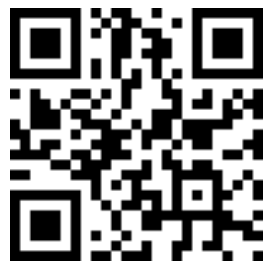

ORCIID

(1) 0000-0002-6875-3215

José Henry Osorio
(Fernandes et al., 2009). The main risk factors for acquiring myiasis are bad hygiene habits and low socioeconomic status (Marquez et al., 2007). The main used systems for sorting outmyiasis, are the classification, proposed by Bishopp (James, 1947) with some modifications (Zumpt, 1965) or anatomical classification, which is useful for diagnosis and classification of the infestation related to the location on the host; and ecological classification which is focused on level of parasitism of the parasite and the host (Patton, 1922). The last one together with the specie life cycle, 
is very important when programs of plague eradication are designed. Another system based on the degree of parasitism shown by the fly is also used, as the same location can be infested by different species and a single species can be found in more than one anatomical location (Mathison and Pritt, 2014). Myiasis are caused by species into obligatory, facultative, and accidental pattern (Hall and Wall, 1995). Skin wounds, eyes, nose, throat, and urogenital tract are considered common infection sites (Safdar et al., 2003; Kim et al., 2009; Salimi et al., 2010; Maleki Ravasan et al., 2012; Graffi et al., 2013). Different treatments are proposed such as cleaning the site of myiasis, as well as the use of topic or systemic drugs (Fydryszewski, 2103). For some clinicians sometimes it is difficult to differentiate between the good or the bad role of larvae in different tissues and the implications of a wrong diagnosis and treatment.

\section{Materials and methods}

The patient was a 67 year-old woman who resided in an urban area of Chinchiná, a municipality located in the department of Caldas in Colombia, $17 \mathrm{~km}$ (11 mi) Southwest of Manizales the Capital of Caldas. Chinchiná is situated at $5^{\circ} 0^{\prime} \mathrm{N}$ $75^{\circ} 35^{\prime} \mathrm{W}$, its elevation is $1,360 \mathrm{~m}(4,462$ feet), and has a mean temperature of approximately $20^{\circ} \mathrm{C}$. The patient was admitted to emergency department of the Public Hospital San Marcos in Chinchiná, Colombia in September 2014, where the caregiver declared she was presenting a bad odor. At clinical exam an abandoned aspect was observed and also she was infested by lice and fleas. She had an antecedent of stroke some years ago and presented left spastic palsy, with very limited walking, hearing loss and deficient speech, a body mass index of 16 was obtained, and a malnutrition stage was diagnosed. Sings of infection was also diagnosed based on an altered blood analysis. After shaving the head, $2 \mathrm{~cm} \times 4 \mathrm{~cm}$ lesion was observed were larvae emerged (Figure 1). The first

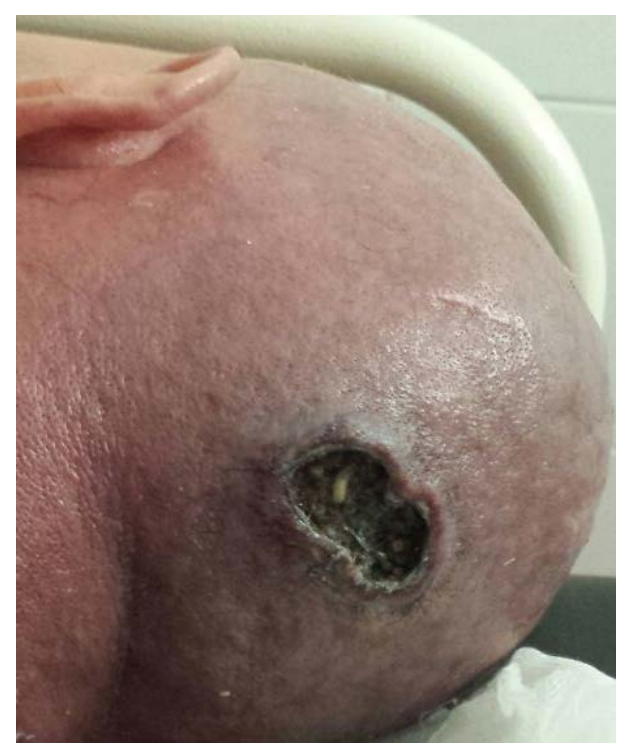

Figure 1. Human myiasis caused by Cochliomyia hominivorax in occipital region of a 67 years old woman. $2 \mathrm{~cm} \mathrm{x} 4 \mathrm{~cm}$ lesion was observed as well as larva inside the tissue.

doctor, a surgeon who attended the case judged that those larvae were benefic for the patient, arguing that flies whose larvae feed on dead animals will sometimes lay their eggs on necrotic or gangrenous tissue of living animals or humans, to clean this kind of tissue. In order to provide a good environment for maggots to feed, as sufficient oxygen supply is a prerequisite and a dry environment needs to be avoided, it was then ordered to cover softly with clean chiffon the site of myiasis, and also moistening it with saline soaks each $12 \mathrm{~h}$ was recommended. For bacterial infection control, $1 \mathrm{~g}$ of intravenous oxacillin each $6 \mathrm{~h}$ was administered and $500 \mathrm{mg}$ of acetaminophen each $6 \mathrm{~h}$ for pain control were provided. After $24 \mathrm{~h}$ a second medical staff evaluated the case finding an increased size $(5 \mathrm{~cm} \mathrm{x} 6 \mathrm{~cm})$ of the lesion (Figure 2) with bigger larvae, and more swollen tissue surrounding the lesion. It was then decided to retire mechanically all possible larvae, with extensive wound exploration, and debridement of necrotic tissue of the borders; ivermectin (8 mg/40 kg) was prescribed in a single oral dose according to description, dosage, and directions to kill 


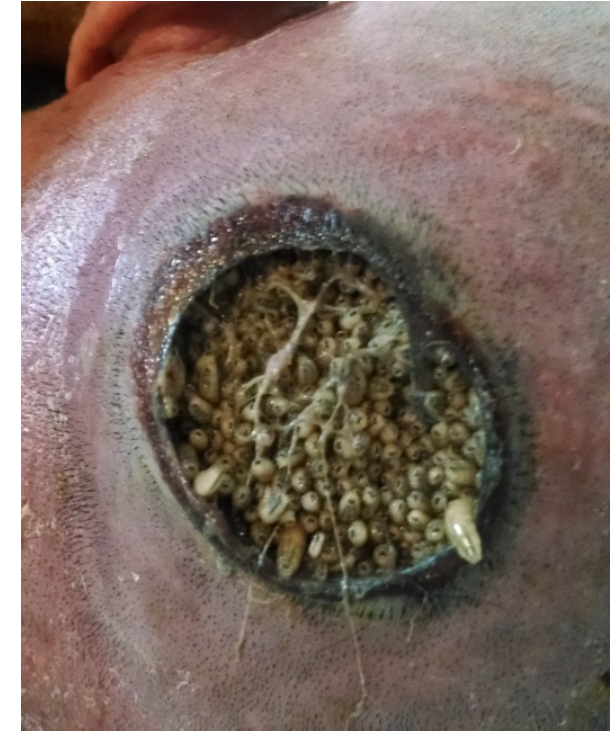

Figure 2. Human myiasis caused by Cochliomyia hominivorax. Increased lesion of $4 \mathrm{~cm} \times 6 \mathrm{~cm}$ after $24 \mathrm{~h}$ of initial treatment, with larvae coming out of the lesion.

the larvae, keeping antibiotic and pain control management. The patient, who at the time was in an emergency ward, was moved to a single room with a prescription of washing the lesion daily with saline solution and after to apply clostridiopeptidase A (collagenase and associated proteases) which are indicated for enzymatic debridement of necrotizing wounds, keeping the antibiotic and pain control treatment. Extracted larvae after the first procedure and some obtained $24 \mathrm{~h}$ later were collected, counted and carried out to Laboratory of Veterinary Parasitology at Universidad de Caldas in Manizales, Colombia, for identification and classification.

\section{Results}

According to anatomical
classification, the studied myiasis
corresponds to a cutaneous myiasis, wound
myiasis. All 132 larvae that were collected
from the patient were in the third instar. All
individuals were identified as belonging to
species Cochliomyia hominivorax. (Figures
3, 4, and 5). After larvae extraction, it was

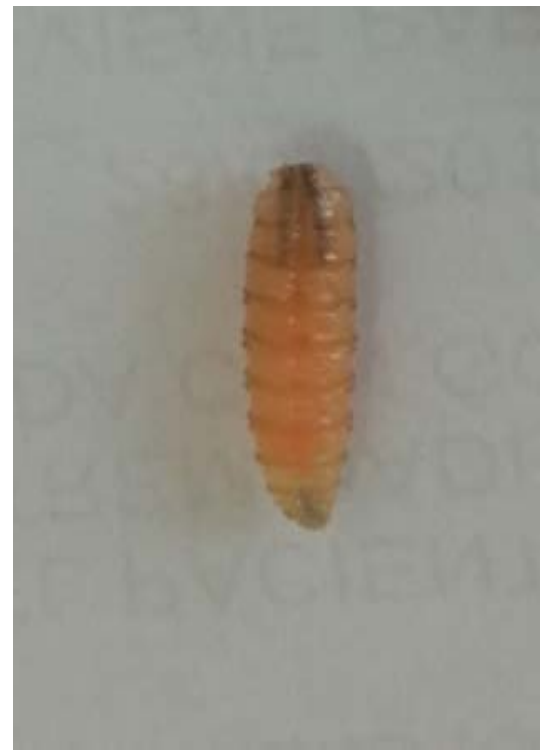

Figure 3. First view of larva extracted from occipital region of the patient. 'Smooth' larva, with spine bands but no obvious body processes except on last segment.

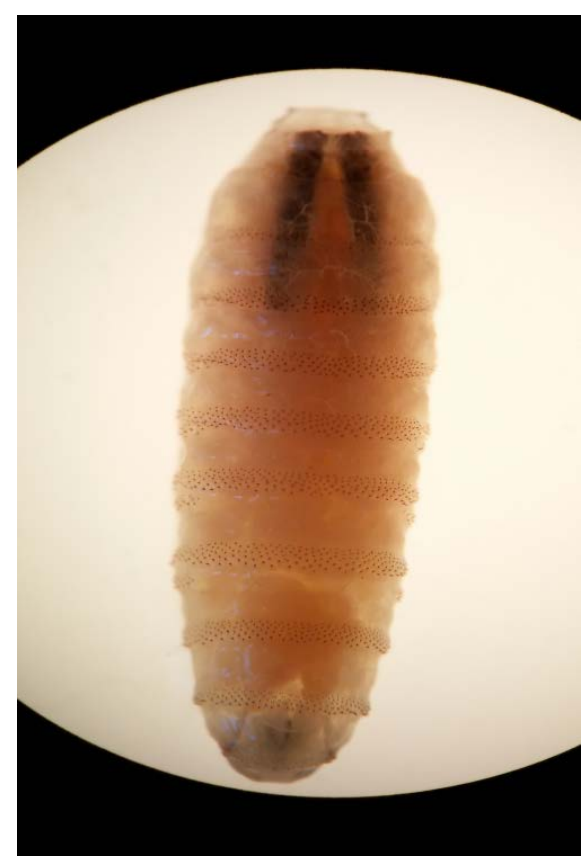

Figure 4. Third instar larva of Cochliomyia hominivorax. Dorsal tracheal trunks darkly pigmented and bands cuticular spines can be observed. 


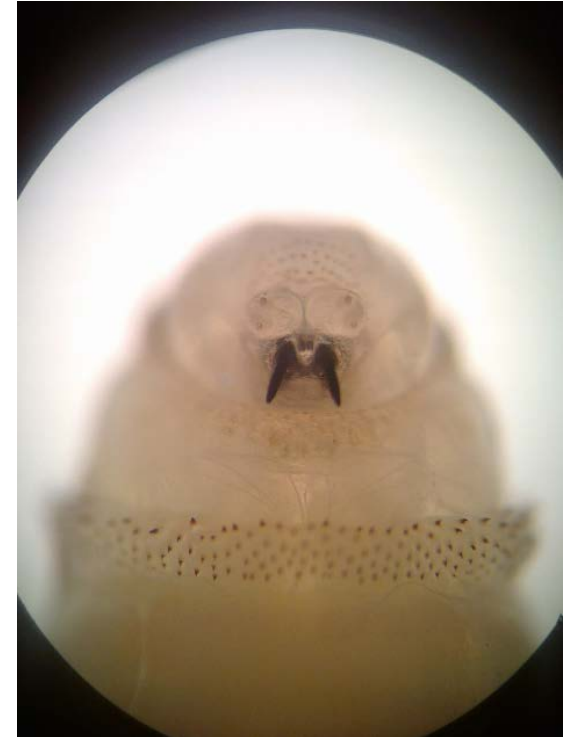

Figure 5. Third instar larva of Cochliomyia hominivorax. Maxillary hooks andbands cuticular spines can be observed.

observed part of the bone exposed (Figure 6). Skull X-ray showed an occipital big hole on flesh without affecting bone tissue (Figure 7). The established treatment and the use of ivermectin to kill third instar larvae in the patient were effective. Evolution of lesion was satisfactory one week later (Figure 8). Finally clinical evolution was satisfactory for patient. A better aspect of the patient was observed with some weight recovered. Management by hospital social work was recommended as well as the intervention of the personnel from municipality administration, searching to guarantee adequate nursery care for the above mentioned person.

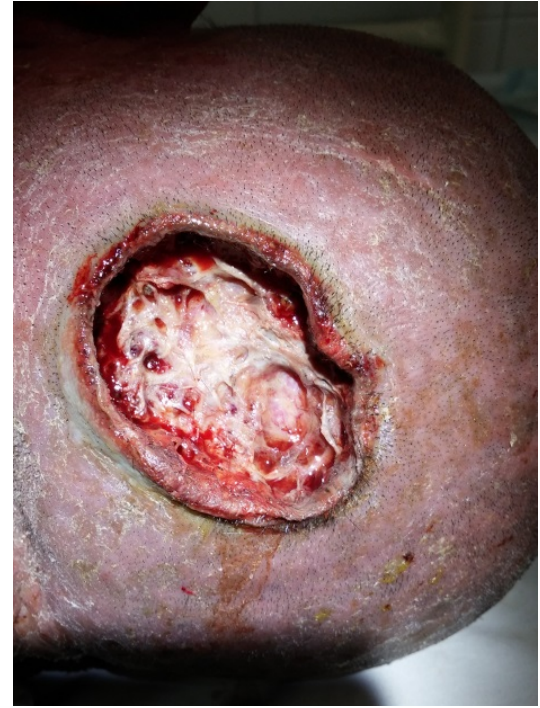

Figure 6. Lesion by larvae of Cochliomyia hominivorax, after mechanically retirement of all possible larvae. Extensive wound exploration as performed with debridement of necrotic tissue of the borders. Part of the bone was already exposed.

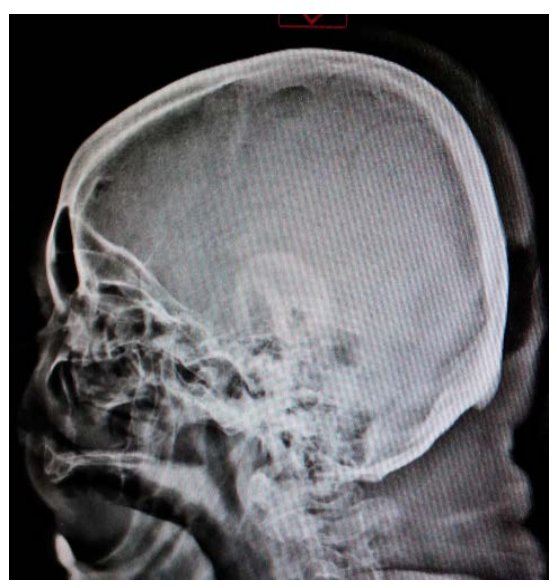

Figure 7. Skull X-ray showing an occipital big hole on flesh without affecting bone tissue. 


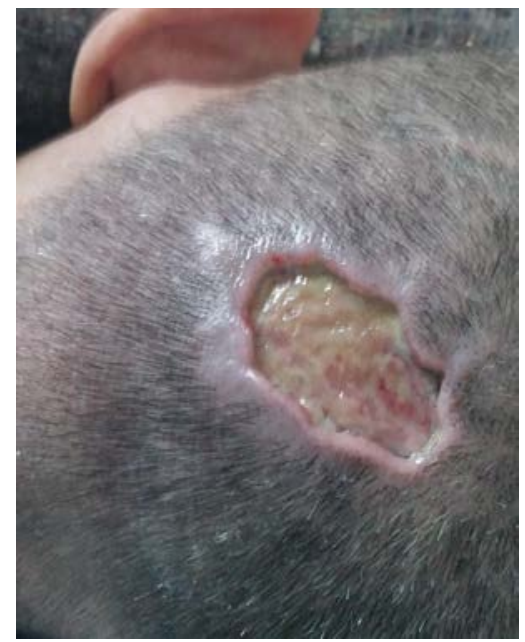

\section{Discusion}

useful classification of myiasis (Francesconi and Lupi, 2012), bringing into account the anatomical location of myiasis and myiasis in special clinical settings (Table 1). Clinical manifestations of cutaneous myiasis are mainly furuncular, caused by Dermatobia hominis, Cordylobia anthropophaga, Wohlfahrtia vigil, and the Cuterebra species; creeping (migratory), due mainly to Gasterophilus and Hypoderma; and wound (traumatic) myiasis

Figure 8. Clinical evolution of the patient 8 days later. Regenerative tissue can be observed.

Table 1. Anatomical location of myiasis and myiasis in special clinical settings.

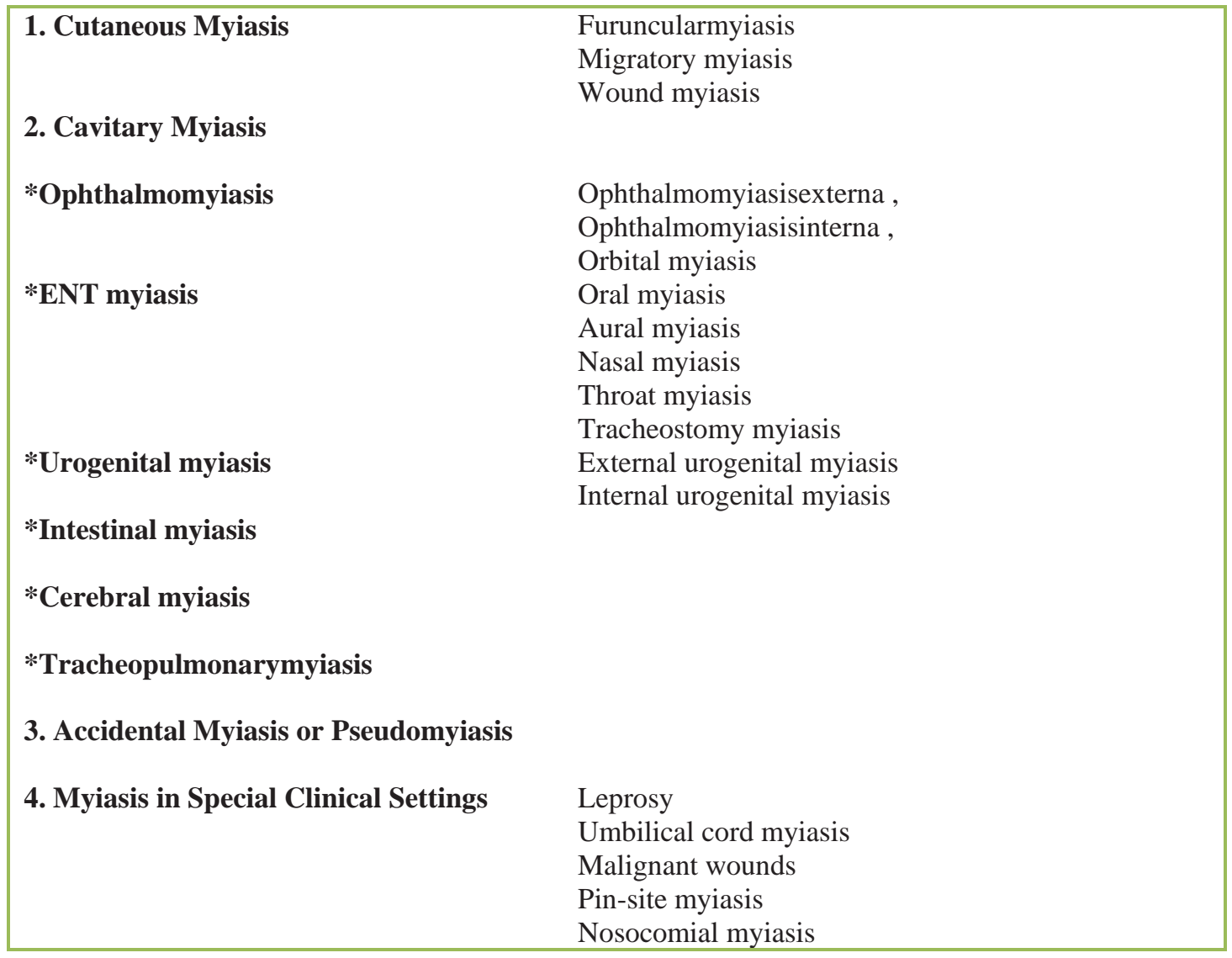

where screwworm flies such as Cochliomyia hominivorax, Chrysomya bezziana and Wohlfahrtia magnifica can produce it (Robbins, 2010). Wound myiasis, the case of the patient of the present study, is the most frequently 
encountered clinical form of cutaneous myiasis (Diaz, 2009). Other agents of wound myiasis include Dermatobia hominis (Romero-Cabello et al., 2004), Musca domestica (Koss et al., 2004), Calliphora vicina (Denion et al., 2004), Phormia regina (Miller et al., 1990), Parasarcophaga argyrostoma (Burgess and Spraggs, 1992), L. sericata (Visciarelli et al., 2007), Chrysomya albiceps, Lucilia cuprina, Sarcodexia lambens and Chrysomya megacephala (Fernandes et al., 2009). Wound myiasis is produced, when fly larvae infest the open wounds of the host; necrotic, hemorrhaging, or pus-filled lesions predispose flies oviposit, especially wounds with alkaline discharges $(\mathrm{pH} 7.1$ to 7.5) (Goddard, 2003). Usually only one species can be found in the lesion, although mixed infestation can occur (Szpila et al., 2014). Persons with the inability to discourage flies from depositing eggs or larvae in wounds, such us some abuse drugs users, alcoholics, psychiatric patients, elderly patients without adequate nursery care or helpless patients are at risk of suffering wound myiasis (Kokcam and Saki, 2005). The females often oviposit on or near a wound between 100 to 500 eggs; the increased size of lesions is due to the larvae growing, as they are eating patient's tissues permanently, as maggots can never reproduce in the wound since they are still in the larval stage and too immature to do so. Reproduction can only occur when they become adult flies and mate, which is the final cause of natural infection observed in patients presenting myiasis (RuikzMartinez, 1996). Larvae start feeding after hatching, causing foul-smelling and bloody discharge most of the times, with destruction of tissue and a bloody discharge, and a very swollen tissues around the lesion (Visciarelli et al., 2007). When more mature larvae are, invasion is worse presenting often local pain and secondary bacterial infection (de Kaminsky, 1993), and finallythe infested person may die from tissue destruction. In the present case fever, chills, bleeding, and leukocytosis and hypereosinophilia occurred, being characteristic in many wound myiasis (Bailey, 2013).The main options of treatment are:toremove the maggots mechanically or surgically, which can be facilitated applying fifteen percent chloroform in olive oil or another oil or ether to immobilize the larvae and facilitate maggot removal; to administer systemic treatment, using ivermectine where an oral dose of $200 \mathrm{mg} / \mathrm{kg}$ can be used (Jelinek et al., 1995); to produce hypoxia on the affected region to force the emergence of the larva, using a thick layer of petrolatum, with its removal every $3 \mathrm{~h}$ until the complete removal of the larvae (Mariwalla et al., 2007); and to applicate toxic substances to the larvae and eggs, using $1 \%$ ivermectin in a propylene glycol solution, maximum of $400 \mathrm{mg} / \mathrm{kg}$ of body weight, applied directly to the affected area for $2 \mathrm{~h}$ and washed with saline solution (Victoria et al., 1999). Clinicians need to be careful when facing a myiasis case as there are thousands of species of flies, each with its own habits and life cycle, and also with specific requirements. That is why some fly larvae feed on plants or animal blood or tissues, while others feed on rotting organic material. Some maggots will feed only on dead tissue, some only on live tissue, and some on live or dead tissue (Herbinger et al., 2011). When chronic wounds are very difficult to treat, such as non-healing ulcers with fibrotic tissue, dead necrotic slough, and multiple infections; there is scientific evidence that the removal of foreign debris and devitalized or contaminated tissues from a wound bed, a process called debridement, can be used (Sun et al., 2014). The technique known historically as maggot therapy, requires larvae extracted from "blow flies" (Calliphoridae); and the species used most commonly is Lucilia sericata, the common green bottle fly (Campbell and Campbell, 2014). However although the maggots debride wounds by dissolving necrotic tissue, vital tissue can be debride as well when dose is too high (Dumville, 2009) or time of treatment is not appropriate (Opletova, 2012). It has been pointed out that maggot secretions are also effective against some antibiotic-resistant bacteria and have been shown to possess potent antimicrobial activity. Those secretions believed to have broad-spectrum 
antimicrobial activity include allantoin, urea, phenylacetic acid, phenylacetaldehyde, calcium carbonate, proteolytic enzymes, and many others (Tellez et al., 2012). In vitro studies have shown that maggots inhibit and destroy a wide range of pathogenic bacteria including methicillin-resistant Staphylococcus aureus (MRSA), group A and B streptococci, and Gram-positive aerobic and anaerobic strains (Takemura-Uchiyama et al., 2013). All maggots used for debridement are specialized and grown in a laboratory setting, this ensures that the larvae are sterilized in order to prevent secondary infections caused by microbes carried in by the maggots (Sherman, 2009). Then clinicians need to understand the difference between a therapeutic uses of larvae and a natural infestation, where treatment as to be performed.

\section{Conclusion}

Occurrences of traumatic myiasis in humans represent serious public health concerns.Health personnel dealing with patients presenting traumatic myiasis, have to initiate immediate treatment to eliminate the larvae using the available methods, in order to guard the patient'ssecurity. It is necessary to understand that Magoot theraphy has to be planned, as an organized treatment desirable for very specific patients suffering of some determined pathologies.

\section{Acknowledgements}

To Dr Luz Nelvia Gomez from San Marcos Hospital Emergency Department who permitted me to re-evaluate and treat the case patient. To Julio Cesar Duque medical student from Universidad de Manizales, who provided me the photo of Figure 1. To Dr Liseth Tavera from San Marcos Hospital Emergency Department who provided me the photo of Figure 2. To Dr Etna Julieth Giraldo, from Laboratory of Veterinary Parasitology at Universidad de Caldas, who helped me in the identification and classification of larvae.

\section{References}

Aggarwal, A.; Daniel, M. J.; Shetty, R.S.; Kumar, B. N.; Sumalatha, C. H.; Srikanth, E.; Rai, S.; Malik, R. Oral myiasis caused by Chrysomya bezziana in anterior maxilla. Case Reports in Dentistry, v. 2014, Article ID 518427, 2014. http://dx.doi.org/10.1155/2014/518427

Bailey, M. S. Tropical skin diseases in British military personnel. J. R. Army. Med. Corps., v. 159, no. 3, p. 224-228, 2013.

Burgess, I.; Spraggs, P. D. R. Myiasis due to Parasarcophaga argyrostoma: first recorded case in Britain. Clin. Exp. Dermatol., v. 17, p. 261-263, 1992.

Campbell, N.; Campbell, D. A retrospective, quality improvement review of maggot debridement therapy outcomes in a foot and leg ulcer clinic. Ostomy Wound Manage, v. 60, no. 7, p. 16-25, 2014.

De Kaminsky, R. G. Nosocomial myiasis by Cochliomyia hominivorax in Honduras. Trans. R. Soc. Trop. Med. Hyg., v. 87, p. 199-200, 1993.

Denion, E.; Dalens, P. H.; Couppié, P.; Aznar, C.; Sainte-Marie, D.; Carme, B.; Petitbon, J.; Pradinaud, R.; Gérard, M. External ophthalmomyiasis caused by Dermato biahominis: a retrospective study of nine cases and a review of the literature. Acta Ophthalmol. Scand., v. 82, p. 576-584, 2004.

Diaz, J. H. Myiasis and tungiasis. In: Mandell, G. L.; Bennett, J. E.; Dolin, R. (Eds.). Principles and practice of infectious diseases. Philadelphia, PA: Elsevier, 2009. v. 2.

Dumville, J. C.; Worthy, G.; Soares, M. O.; Bland, J. M.; Cullum, N.; Dowson, C.; Iglesias, C.; McCaughan, D.; Mitchell, J. L.; Nelson, E. A.; Torgerson, D. J. VenUS II team.VenUS II: a randomised controlled trial of larval therapy in the management of leg ulcers. Health. Technol. Assess., v. 13, no. 55, p. 1-182, 2009.

Fernandes, L. F.; Pimenta, F. C.; Fernandes, F. F. First report of human myiasis in Goiás State, Brazil: frequency of different types of myiasis, their various etiological agents, and associated factors. J. Parasitol., v. 95, p. 32-38, 2009.

Fydryszewski, N. A. Myiasis: diagnosis, treatment and medical use of maggots. Clin. Lab. Sci., v. 26, no. 2, p. 76-81, 2013.

Goddard, J. Physician's guide to arthropods of medical importance. 4. ed. Boca Raton, FL: CRC Press, 2003. 
Graffi, S.; Peretz, A.; Wilamowski, A.; Schnur, H.; Akad, F.; Naftali, M. External ophthalmomyiasis caused by a rare infesting larva, Sarcophaga argyrostoma. Case Reports in Ophthalmological Medicine, v. 2013, Article ID 850865, 2013. http://dx.doi.org/10.1155/2013/850865

Hall, M.; Wall, R. Myiasis of humans and domestic animals. Adv. Parasitol., v. 35, p. 257-334, 1995.

Herbinger, K. H.; Siess, C.; Nothdurft, H. D.; von Sonnenburg, F.; Löscher, T. Skin disorders among travellers returning from tropical and non-tropical countries consulting a travel medicine clinic. Trop. Med. Int. Health, v. 16, no. 11, p. 1457-1464, 2011.

Hodge, G. R.; Dvorak, W. S. Variation in pitch canker resistance among provenances of Pinus patula and Pinus tecunumanii from Mexico and Central America. New Forests, v. 33, p. 193206, 2007.

James, M. T. The flies that cause myiasis in man. Washington, D.C.: Department of Agriculture, 1947. (Miscellaneous Publication, 631).

Jelinek, T.; Nothdurft, H. D.; Rieder, N.; Loscher, T. Cutaneous myiasis: review of 13 cases in travelers returning from tropical countries. Int. J. Dermatol., v. 34, p. 624-626, 1995.

Kim, J. S.; Seo, P. W.; Kim, J. W.; Go, J. H.; Jang, S. C.; Lee, H. J.; Seo, M. A nasal myiasis in a 76-year-old female in Korea. Korean $\mathbf{J}$. Parasitol., v. 47, no. 4, p. 405-407, 2009.

Kokcam, I.; Saki, C. E. A case of cutaneous myiasis caused by Wohlfahrtia magnifica. J. Dermatol., v. 32, p. 459-463, 2005.

Koss, T.; Lanatra, N.; Stiller, M. J.; Grossman, M. E. An unusual combination: lipedema with myiasis. J. Am. Acad. Dermatol., v. 50, p. 969-972, 2004.

Laplaud, A. L.; Sohyer-Lebreuilly, I.; Dompmartin, A. Maggot therapy for wound debridement: a randomized multicenter trial. Arch. Dermatol., v. 148, no. 4, p. 432-438, 2012.

Maleki Ravasan, N.; Shayeghi, M.; Najibi, B.; Oshaghi, M. A. Infantile nosocomial myiasis in iran. J. Arthropod Borne Dis., v. 6, no. 2, p. 156-163, 2012.

Mariwalla, K.; Langhan, M.; Welch, K. A.; Kaplan, D. H. Cutaneous myiasis associated with scalp psoriasis. J. Am. Acad. Dermatol., v. 57, p. S51-S52, 2007.
Marquez, A. T.; Mattos, M. D.; Nascimento, S. B. Myiasis associated with some socioeconomic factors in five urban areas of the State of Rio de Janeiro. Rev. Soc. Bras. Med. Trop., v. 40, p. 175-180, 2007.

Mathison, B. A.; Pritt, B. S. Laboratory identification of arthropod ectoparasites. Clin. Microbiol. Rev., v. 27, no. 1, p. 48-67, 2014. http://dx.doi.or/10.1128/CMR.00008-13

Miller, K. B.; Hribar, L. J.; Sanders, L. J. Human myiasis caused by Phormia regina in Pennsylvania. J. Am. Podiatr. Med. Assoc., v. 80, p. 600-602, 1990.

Opletalová, K.; Blaizot, X.; Mourgeon, B.; Chêne, Y.; Creveuil, C.; Combemale, P.; Laplaud, A. L.; Sohyer-Lebreuilly, I.; Dompmartin, A. Maggot therapy for wound debridement: a randomized multicenter trial. Arch. Dermatol., v. 148 , no. 4, p. 432-438, 2012.

Patton, W. S. Notes on myiasis producing Diptera of man and animals. Bull. Entomol. Res., v. 12, p. 239-261, 1922.

Robbins, K.; Khachemoune, A. Cutaneous myiasis: a review of the common types of myiasis. Int. J. Dermatol., v. 49, no. 10, p. 1092-1098, 2010.

Romero-Cabello, R.; Sánchez-Vega, J. T.; TayZavala, J.; Ruiz-Sanchez, D.; Calderon-Romero, L. Miasis asociada a síndrome de complejo vascular periférico. Parasitol. Latinoam., v. 59, p. 159-161, 2004.

Ruíz-Martínez, I.; Gómez, F.; Pérez, J. M.; Poudevigne, F. A. The role of botfly myiasis due to Dermatobia hominis L. Jr. (Diptera: Cuterebridae) as a predisposing factor to New World screwworm myiasis (Cochliomyia hominivorax Coquerel) (Diptera: Calliphoridae). Ann. N. Y. Acad. Sci., v. 791, p. 434-442, 1996.

Safdar, N.; Young, D. K.; Andes, D. Autochthonous furuncular myiasis in the United States: case report and literature review. Clin. Infect. Dis., v. 36, no. 7, p. e73-e80, 2003.

Salimi, M.; Edalat, H.; Jourabchi, A.; Oshaghi, M. First report of human nasal myiasis caused by Eristalis tenax in Iran (Diptera: Syrphidae). Iran. J. Arthropod. Borne. Dis., 4(1):77-80, 2010.

Sherman, R. A. Maggot therapy takes us back to the future of wound care: new and improved maggot therapy for the 21st century. J. Diabetes Sci. Technol., v. 3, no. 2, p. 336-344, 2009. 
Sun, X.; Jiang, K.; Chen, J.; Wu, L.; Lu, H.; Wang, A.; Wang, J. A systematic review of maggot debridement therapy for chronically infected wounds and ulcers. Int. J. Infect. Dis., v. 25, p. 32-37, 2014.

Szpila, K.; Hall M. J.; Wardhana, A. H.; Pape, T. Morphology of the first instar larva of obligatory traumatic myiasis agents (Diptera: Calliphoridae, Sarcophagidae). Parasitol. Res., v. 113, no. 5, p. 1629-40, 2014.

Takemura-Uchiyama, I.; Uchiyama, J.; Kato, S.; Inoue, T.; Ujihara, T.; Ohara, N.; Daibata, M.; Matsuzaki, S. Evaluating efficacy of bacteriophage therapy against Staphylococcus aureus infections using a silkworm larval infection model. FEMS Microbiol. Lett., v. 347, no. 1, p. 52-60, 2013.
Téllez, G. A.; Acero, M. A.; Pineda, L. A.; Castaño, J. C. Effect of maggot therapy on minimally necrotic tissues: characterization of larval enzymatic excretion/secretion. Biomedica, v. 32, no. 3, p. 312-320, 2012.

Victoria, J.; Trujillo, R.; Barreto, M. Myiasis: a successful treatment with topical ivermectin. Int. J. Dermatol., v. 38, p. 142-144, 1999.

Visciarelli. E.; Costamagna, S.; Lucchi, L.; Basabe, N. Human myiasis in Bahía Blanca, Argentina: period 2000/2005. Neotrop. Entomol., v. 36, p. 605-611, 2007.

Zumpt, F. Myiasis in man and animals in the Old World. London: Butter-Worths, 1965.

License information: This is an open-access article distributed under the terms of the Creative Commons Attribution License, which permits unrestricted use, distribution, and reproduction in any medium, provided the original work is properly cited. 